\title{
Evaluation and Analysis of the Deployment of Green Communication Technology in GSM
}

\author{
B.I.Bakare, Sunny Orike and D.I.Oko
}

\begin{abstract}
This paper presents an evaluation and analysis of the deployment of green communication technology in Nigeria. Most base stations in Nigeria uses diesel generators to power their Cell Sites, this has been identified as a problem if not checked because it will continue to add to the Carbon dioxide emission in the atmosphere and hence the depletion of the ozone layer. Green Communication Technology was proposed to solve this problem. Energy deployed are photovoltaic and wind turbine (PV/WT) energy while diesel generator (DG) will still be used as a backup. With the use of hybrid technology (PV/WT/DG), carbon emission will be reduced by $70 \%$ or more, efficiency will be achieved.. The results obtained from this research work are based on economics cost, efficiency, power outputs per year and carbon emissions. , in terms of efficiency the DG only system has a mean efficiency output of $8.18 \%$ and mean efficiency of $25 \%$ while the proposed system has a mean efficiency output of $14.8 \%$ and a mean efficiency of $27.5 \%$ for PV and $21.3 \%$ of WT, electrical production of DG only is $119439 \mathrm{kWh} / \mathrm{yr}$ while Hybrid Systems (HBS) has electricity production of $124,488 \mathrm{kWh} / \mathrm{yr}$, base on life cycle DG only system operate for 3yr and max of 8yrs while HBS operate for $25 \mathrm{yrs}$ above, the carbon emissions for DG only system for $\mathrm{CO} 2, \mathrm{CO}$, $\mathrm{NO} 2$ are $75,033,473,444 \mathrm{~kg} / \mathrm{yr}$ respectively and $\mathrm{HBS}$ for $\mathrm{CO} 2$, $\mathrm{CO}, \mathrm{NO} 2$ is $264,1.79$ and $2.04 \mathrm{~kg} / \mathrm{yr}$ respectively. From the result obtained it can be concluded that the proposed system is better than the existing system, therefore, it can be recommended for GSM operators in Nigeria and any developing nation.
\end{abstract}

Index Terms-Green Communication, Hybrid System, Photovoltaic, Reliability and wind turbine.

\section{INTRODUCTION}

Global System for Mobile (GSM) Communications in Nigeria was deployed in 2001, this has brought tremendous growth in the industry because it is possible for GSM users to perform various services using their communications gadget such as internet banking, videos streaming, high-speed internet activities etc. GSM has become an important economic and social asset also, an essential tool for transmitting or exchanging information for everybody [6]. The continuous growth and yearly increase in GSM phones and other wireless communication equipment in Nigeria and other parts of the world are spectacular, it has reduced the world into a global village and most importantly into a unit in [5].

However, due to continued end-user demand, there is a continues sitting of base stations in many locations in Nigeria, but because of the power problem in the country, operators depend on diesel generators to power their facilities. Therefore, if not checked the effect it creates will be life-

B.I.Bakare is with the Electrical Engineering Department, Rivers State University Port Harcourt, Rivers State, Nigeria (e-Mail Bakare.bodunrin@ust.edu.ng) threatening, therefore green communication energy should be deployed to check this problem. Green communication technology in this context means the use of carbon emissionfree source of power, which is feasible, efficient and at the same time do the same work like any other power sources used in base stations, which is developed and reliable and is used in a way that protects the environment and conserves natural resources. In addition to the environmental aspects, energy costs also represent a significant portion of network operators' overall operational expenditures (OPEX). While the BSs connected to the electrical grid may cost about 2 to 10 million Naira per year to operate, in [14], if green energy sources are deployed its operational expenditure (OPEX) cost will be greatly reduced.

GSM networks have developed significantly over these past years especially in Nigeria, which can be seen in all the services one can use this GSM to do as stated earlier. As a result of this growth, users always experience data traffic and the number of mobile subscribers has exponentially skyrocketed, thereby prompting many GSM network operators like MTN, Globalcom, etc to install additional GSM base stations (BSs) to meet the increasing demand, in [24] and [14]. Unfortunately, low or no power availability in the rural and urban areas especially developing countries like Nigeria, which can be attributed to so many factors, such as bad government policies and lack GSM operators willingness to look elsewhere for alternative power sources that is viable, but rather chooses to depend on cheap or easy sources of power, therefore, depending solely on diesel generator (DG) in powering their BSs, as a result creating increases in their OPEX every year. However, it should be noted that using DG to power BSs does not present a sustainable option for those network companies that aim to expand and deliver their services to new customers, besides, it is not an eco-system friendly power sources.

Therefore, cost-effectiveness, efficiency, sustainability, and reliability, which are key features of power source requirements for BSs, can be achieved through the exploitation of available energy from solar and wind resources, this is considered a long-term ideal solution for cellular network operators. Moreover, because it is freely available in Nigeria, that is, sunlight and wind are the ideal alternatives that can reliably supply power to remote areas. However, in designing a solar or a wind turbine system its requires a feasibility assessment, and this can be achieved

Sunny Orike is with the Electrical Engineering Department, Rivers State University Port Harcourt, Rivers State, Nigeria

D.I Oko is with the Electrical Engineering Department, Rivers State University Port Harcourt, Rivers State, Nigeria 
through a hi-tech model called HOMER Software, which will access the particular region you want to site your base station, then after modelling work is done, whoever is handling that project will know the perfect power output of that location. They have been many research work carried out on green energy and almost all have proven to be supporting green energy, either by giving a useful idea or backing of the viability of green energy.

\section{EVALUATION OF GREEN COMMUNICATION TECHNOLOGY}

\section{A. Related works}

Reference [5] appraised green communication energy, in which much emphasis was made on efficiency, operational expenses and carbon emission reduction. According to [5]. Energy crisis and climate change are not the only problems the world is facing, the are other bigger problems faced presently in GSM industry and this will continue in future if not checked, as their effects on life and the environment are very obvious and at a very alarming rate. Carbon dioxide (CO2), methane and other carbon emissions (Greenhouse emissions) are responsible for global warming with devastating effect on human existence, therefore, there is a need for green sources of energy which is clean and more reliable than the one presently in use in the industry. Telecommunication network architecture especially the Base station consumes the highest amount of power, and the main reason is because of the poor design of the power amplifier, there designers only considered the range it will cover not thinking of efficiency, therefore when you choose a location for a base station, what should first come to mind is what are the population density, and if there is need for more base station in such location, the next step is what hardware will be best for the locality, while having in mind the energy efficiency of the components in [26];[5]. However, figure 1and 2 shows that base station facilities consume about $57 \%$ other sectors takes the remaining, while in figure 2 power consumption distribution shows that power amplifiers consume the highest percentage about $60 \%$ of it, therefore, to improve this section of base station facilities there is a need for an improved design of PA which will have low or minimal consumption, therefore it is advisable to use or an equipment with high energy efficiency ratio (EER), it should be noted that the PA efficiency decreased in each network generation starting from GSM in 1990 to LTE 2010. But the peak to average power ratio (PAPR) increased to $6.5 \mathrm{~dB}$ in UMTS and $8.5 \mathrm{~dB}$ in LTE. In recent time many types of research have aimed at improving the energy efficiency of PA while maintaining the linearity and increasing the operating bandwidth of BSs. Since 2010 many types of research have shown that the potentially optimized ratio of output power to input power for PA (power efficiency) may reach as high as $60 \%$ to $85 \%[21] ;[27]$.

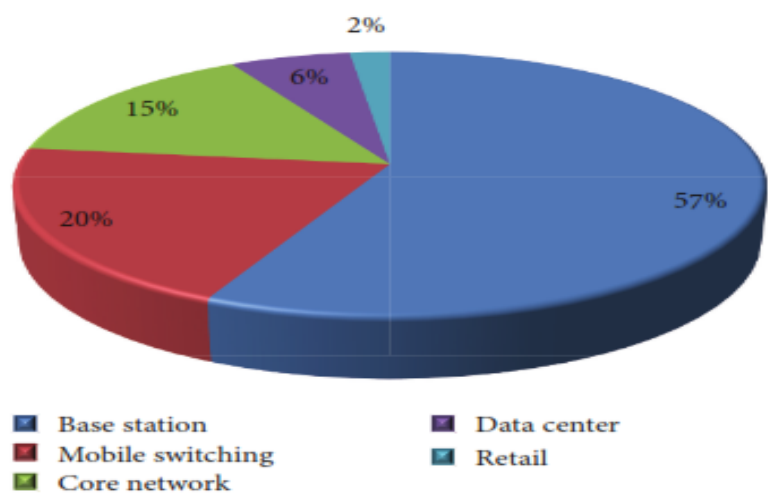

Fig.1. Energy Consumption Composition of a Mobile Operator in [4];[5]

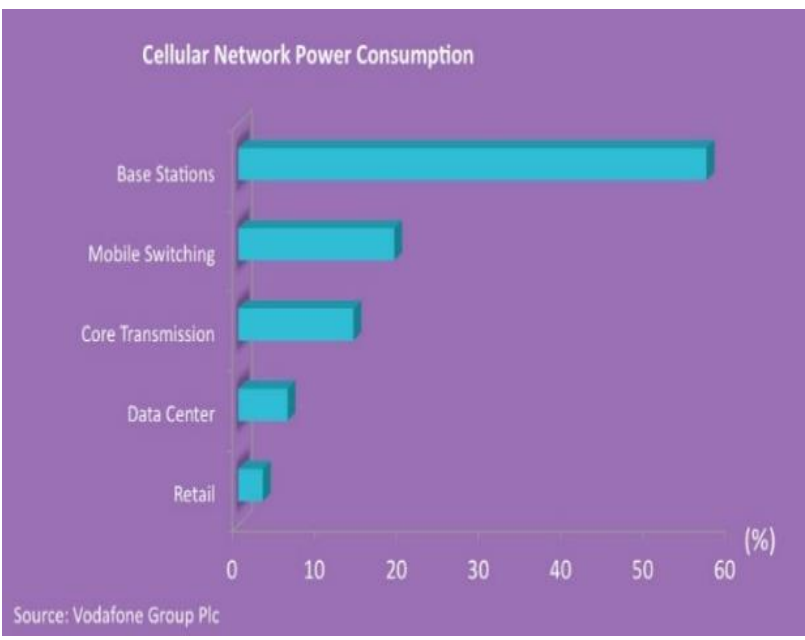

Fig. 2. GSM Power Consumption network Infrastructure Representation [15];[4].

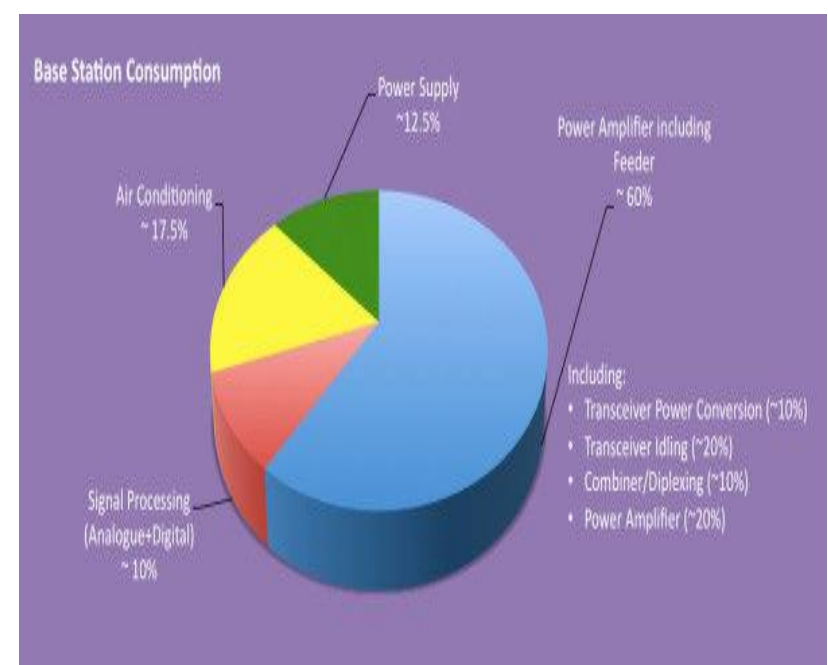

Fig.3. Base Station Power Consumption Distribution in [10];[4].

Planning is an important aspect of setting up GSM base stations, it is a proper practice to reduce the distance between the user equipment (UE) and Base Station, through the use of relay system, because this will increase the data rate and reduce the transmitted power, thereby improving the energy efficiency of both uplink and downlink communication in [19]. Macro-cells are generally designed to provide large 
coverage and are not efficient in providing high data rates. One obvious way to make the cellular networks more powerefficient in order to sustain high-speed data-traffic is by decreasing the propagation distance between nodes, hence reducing the transmission power. Therefore, cellular network deployment solutions based on smaller cells such as micro, pico and femtocells are very promising in this context in [9]. similarly, using either of the relay technique as mentioned is a good idea. But past researches have most times focused on HetNet deployments (multilayer network) in [1]. Each BS type in this architecture has a unique capability, transmit power, range, power consumption, access, backhaul, and operating functionality in [29];[27]. This flexibility gives it an attractive option for increasing network capacity and energy efficiency. More than 40,000 small cells were deployed in 2015 and this number has already increased to over a million and it will keep increasing in future, likely upon the deployment of $5 \mathrm{G}$ technology in [17]; [25].

Deploying smaller cell will reduce the amount of power consumption in the entire base station architecture, but most importantly the PA, therefore, if smaller cells are deployed there is a possibility that efficiency of the network is achieved. Macro-cells are deployed to provide overall coverage, while small cells become active if the demand increases. Based on this approach, a joint deployment strategy was investigated in [24] utilizing micro-cells within a macro-cell network, and the impact on energy consumption was determined. In addition, the researcher considered area power consumption as a performance metric.

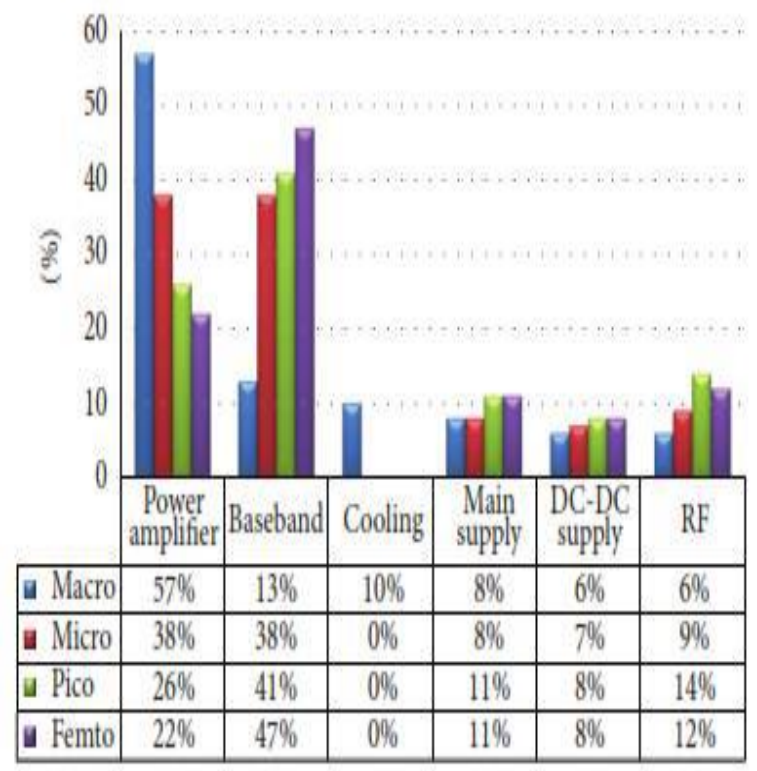

Fig.4. Small Cells Base Station Power Consumption in [4]; [24]
TABLE I: SMALL CELL NETWORK

\begin{tabular}{lll}
\hline \hline Cell type & Cell size & Output Power \\
\hline Macro & $1-30 \mathrm{~km}$ & Tens of watts \\
Micro & $0.4-2 \mathrm{~km}$ & $1-6.3 \mathrm{~W}$ \\
Pico & $4-200 \mathrm{~m}$ & $200 \mathrm{~mW}-2 \mathrm{~W}$ \\
Femto & $10 \mathrm{~m}$ & $20-200 \mathrm{~mW}$ \\
\hline
\end{tabular}

Reference [24] investigated the energy efficiency of both homogeneous (pure microcells and macrocells) and heterogeneous networks consisting of a varying number of microsites, based on the traffic load conditions. From my finding, homogeneous micro-deployment achieves better energy efficiency than heterogeneous network deployment, as the throughput and number of users in the network increase, the best approach to improving the energy efficiency of the network is to deploy more microsites. In addition to the above-mentioned research works, several papers have highlighted the feasibility of using pico24 and femtocells to achieve energy savings, femtocells are the most discussed subject in the literature. Femtocells are the closest to the users in terms of network size; that is, the distances are shorter, which results in less power transmission, thereby increasing energy efficiency and reducing the path loss. It also reduces path loss and improves the throughput of the network. In addition, in [18] the energy efficiency gains that can be achieved through the deployment of femtocells within a microcell, while accounting for the QoS was discussed. The results indicated that the use of femtocells improved the energy consumption of the joint network deployment studied. Reference [14] proposed a new architecture called "FemtoWoC" to improve the energy efficiency through wireless-over-cable (WoC) transmission, a recent study described in [21] offered excellent analytical models for the power consumption in macro-cells, microcells, picocells, and femtocells, I have also investigated classes of network which are: class A network, the researchers considered a femtocellbased network in which, instead of macro-cells, an area is fully covered by femtocells, the results showed that energy consumption was reduced by $82.72-88.37 \%$. class B network, the coverage area was divided into three parts: an urban area, a suburban area, and a rural area, which were covered by femtocells, macro-cells and portable femtocells, respectively. The results obtained show that the total transmitted power was reduced by $78.53-80.19 \%$, in the class C network, femtocells, picocells, microcells, and portable femtocells were allocated in a densely populated urban area, sparsely populated urban areas, suburban areas, and rural areas, respectively, which reduced the total transmitted power by $9.19-9.79 \%$. In the class D network, microcells, picocells, and femtocells were allocated to border regions and macrocells were allocated to the rest of a coverage area. The results obtained showed that the total transmitted power was reduced by $6-6.5 \%$. In the class E network, femtocells were allocated to the boundary region of the macro-cell and turned on in that region when the signal received from the macro-cell BS was too low to successfully receive or generate a call. When all the femtocells were kept on, the macro-cell shrinks in the 
coverage area, the results show that power consumption was reduced by $4-6 \%$, [25]; [29].

Carbon emission footprint generated by the existing system is increasing yearly, if not checked will further increase, as projected in figure 5. However, the data is for a global rating, but it should be noted that developing nations like Nigeria contributes the highest amount of carbon emission because of it continues dependent on a diesel generator to power it GSM and other communications facilities.

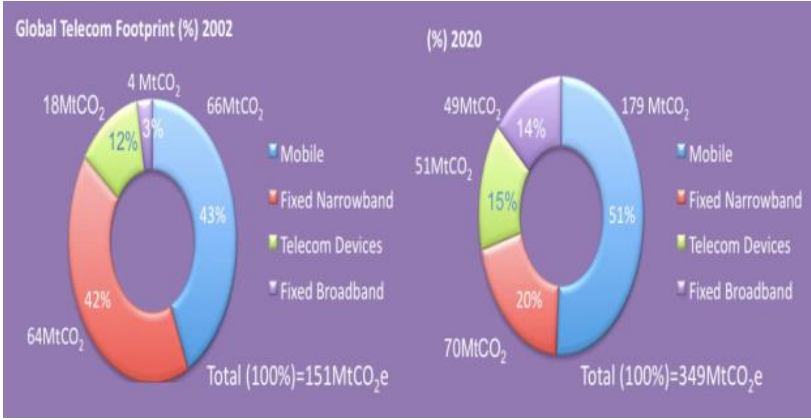

Fig.5. Carbon Footprint Distributed by Telecom from 2002 TO 2020 [15]

\section{GREEN COMMUNICATION TECHNOLOGY DEPLOYMENT}

Green communication technology is a source of power proposed to replace the existing technology using a hybrid system. Figures 6 show the existing system and Figure 7 shows the hybrids system design replacing it. The existing system is mainly to give power to the base station, no consideration for its shortcomings. Whereas, the Hybrid system looks at the deficiencies of the existing system by correcting those errors, like reducing pollutant, and it is environmentally friendly, efficient, cost-friendly and viable.

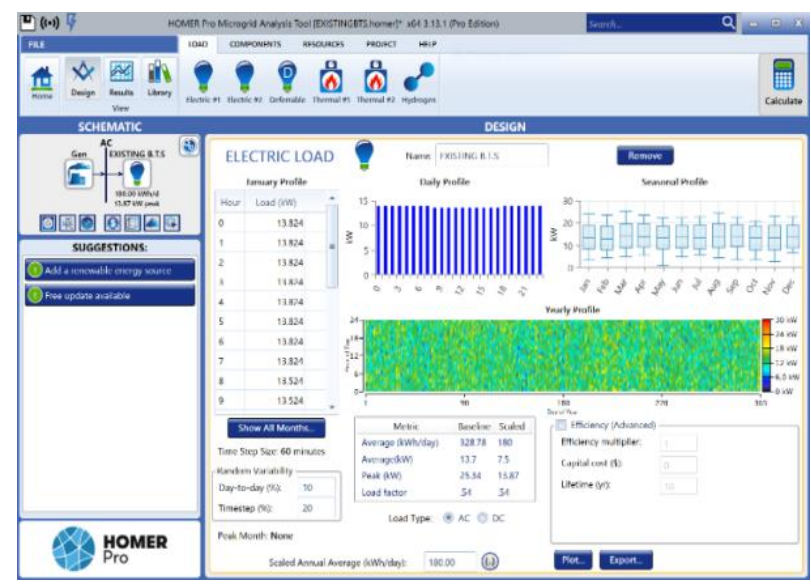

Fig. 6. Base Station Existing Power System Design

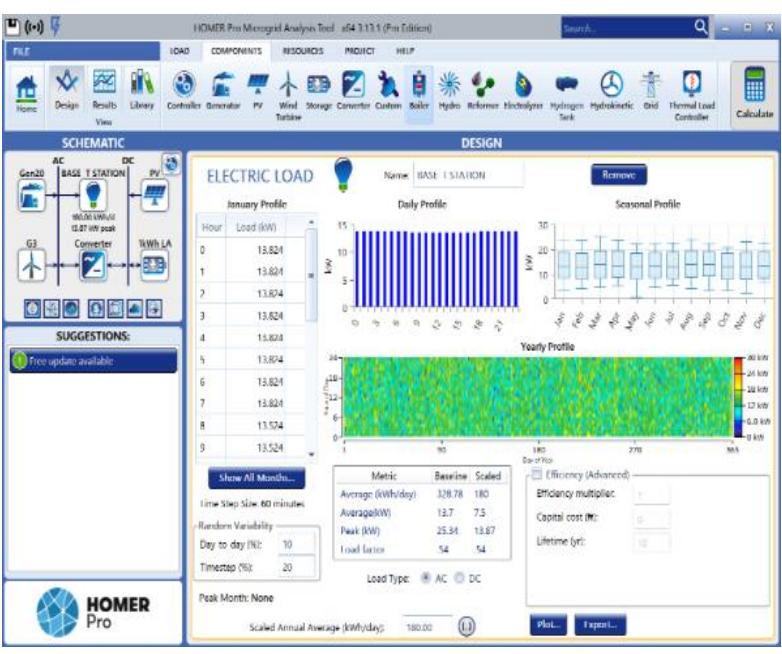

Fig. 7. Proposed Base Station Hybrid Design

From the existing system, which is the diesel generator, as stated above, operators only considered power generated, without looking at other factor involved, like environmental effect, cost implications, efficiency, etc. But what green technology will bring is to investigate all the problem the existing system neglected, as mentioned above. Must operators in Nigeria don't reason in the direction of new innovations, all they considered is the output of what they are using like DG, as far as is serving the purpose. But to achieve what is right they operators in Nigeria must have a mind change, by thinking like most developed countries using this technology. To solve this problem hybrid system should be deployed in base stations, it does not look attractive but is very efficient, and has low-cost implication also clean power system, with these operators have all the balance for a functional base station which is viable. HOMER software is used for visual works, making the operations easy, which will help you simulate your design and at the same time predict how long the designed system will last.

\section{A. Base Station Power System Design}

The design of the proposed base station is an important aspect in this project because it helps to show the difference between your power source and existing source, and how important your new system will replace the existing system. The design in Figure 8 to 9 shows the basic stages in hybrid power design starting from the Load. When the load parameter is known the system is model with respect to it. In this project $13.824 \mathrm{~kW}$ is the peak load, during design some factors like system failure, cost and efficient were considered. 


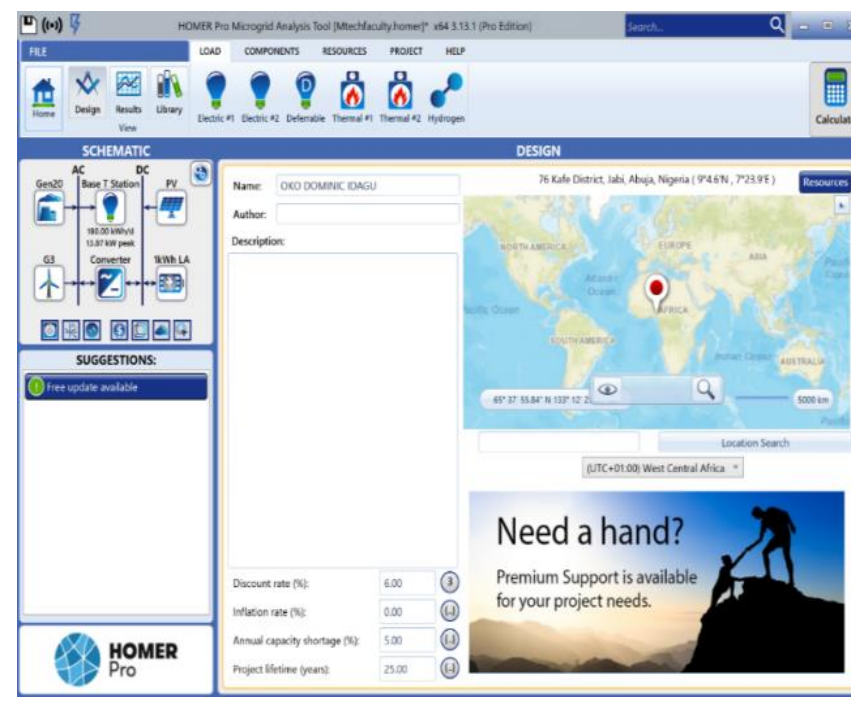

Fig. 8. First Design Stage of Hybrid System

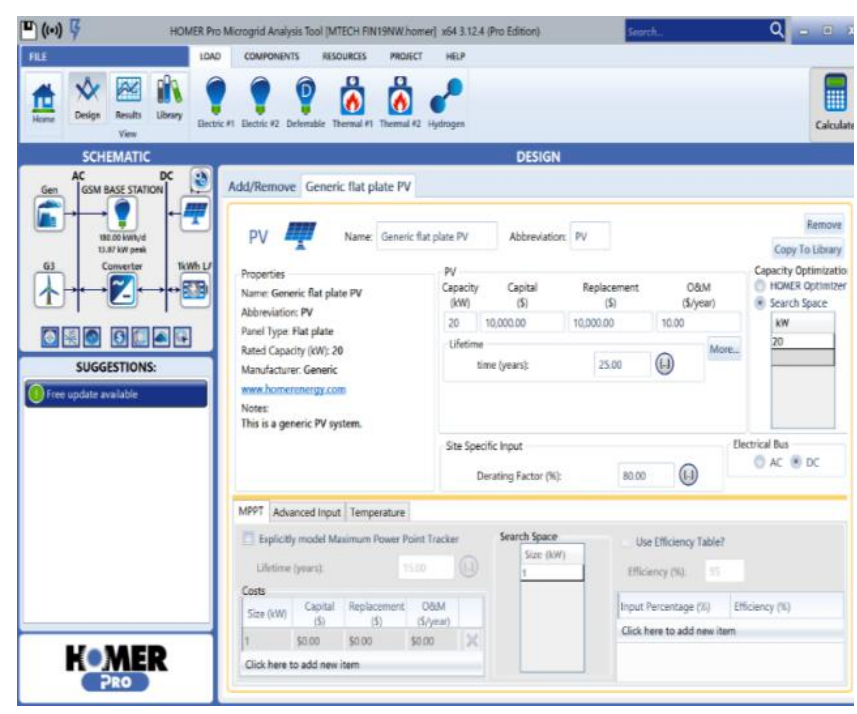

Fig 9. Hybrid PV System Design

\section{B. Analysis of the designed power system}

The analysis of Hybrid power systems can be challenging because of the large number of design options and the uncertainty of key parameters. Moreover, solar radiation adds further complexity, as it may be intermittent, seasonal, and uncertain. The hybrid optimization model for electric renewables (HOMER) was designed to overcome these challenges [8]. Thus, the optimization of a system can also be achieved through Empirical analysis and iterative approach, system reliability model, system cost model, and mathematical model of the entire system, however, they were used to achieve the result for this project.

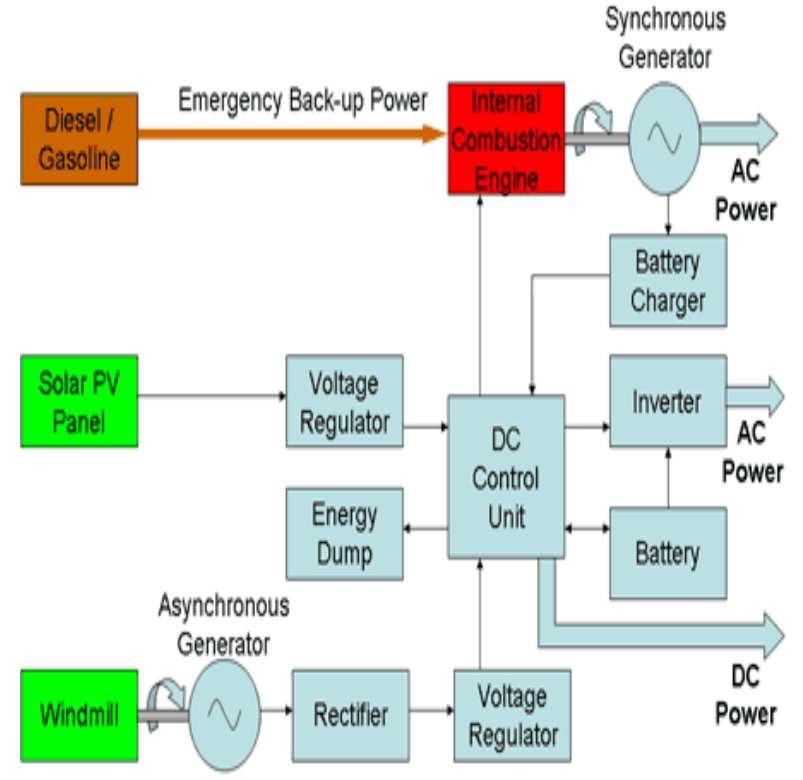

Remote Area Power Systems (RAPS)

Fig. 10. Block Diagram of a Hybrid Power System for Base Station (google search retrieved from http://www.sacredsun.com/solution_112).

From the block diagram above the control unit monitors the process of the output power of the solar system and required power to the cellular base station, and the decision by the control unit is to perform any of the following operations:

Normal Operation: The solar panels and wind turbine feed the required energy to the cellular base station and store excess energy in a battery bank (charge status) to be used at night or when the power output of the solar panels is not enough to cover the load.

Moderate Operation: Power output of the solar panels and the wind turbine is not sufficient to cover the load, in case of a malfunction of the solar panels, or in an inability to provide the energy required to the cellular base station, the battery bank compensates for the shortage of energy. Moreover, the battery bank can supply the cellular base station autonomously at least 3 days, before reaching the maximum depth of discharge (DOD).

Faulty Operation: Power output of the solar panels, wind turbine and battery bank is not sufficient to cover the load, if the battery bank reaches its maximum DOD and loses the ability to supply the cellular base station the required energy, a backup system (public electrical grid in an urban area or a diesel generator in a rural area) supplies energy to the cellular base station. However, this is a rare case because the solar array can cover the load independently. Moreover, if the solar panels and wind turbine fail to support the cellular base station, the battery bank can supply the cellular base station autonomously at least 3 days, before reaching the maximum DOD; which is enough time to fix the solar panels in [11].

However, the backup system is suggested as a backup power source to secure the power supply during maintenance. The alternating current (AC) loads are fed directly from the backup system, and the direct current (DC) load feed occurs via a converter (AC\&DC).In a situation of asymmetrical faults and imbalances, a solution to this kind of problem is rendered, by integrating a standard current regulated voltage 
source inverter in parallel to the load and utility mains so any asymmetrical fault or imbalance can be avoided for sensitive loads. The proposed technique avoids interruption of the power supply during the faults and provides instant protection to critical loads with high power regulating and conditioning capabilities, moreover, use of unsymmetrical faults analysis method with hybrid compensation can be considered in [8].

\section{Base Station Load Analysis}

\section{Radio equipment:}

Radio Unit (Radio Frequency (RF) Conversion and Power Amplification $)=4300 \mathrm{~W}$

Base Band (Signal Processing and Control $)=2300 \mathrm{~W}$

Power conversion equipment:

Power Supply \& Rectifier $=1200 \mathrm{~W}$

Antenna equipment:

$\mathrm{RF}$ feeder $=150 \mathrm{~W}$

Remote Monitoring and Safety (aircraft warning light) $=$ $100 \mathrm{~W}$

\section{Transmission equipment:}

Signal Transmitting $=200 \mathrm{~W}$

Auxiliary equipment:

Security and Lighting $=300 \mathrm{~W}$.

It should be noted that the cooling architecture is designed to address heat generation from radio equipment, power conversion equipment, and other heat equipment.

But the total power of the system is $8550 \mathrm{Kw}$, converting to hourly load $=8550 \mathrm{~W} / \mathrm{h}(8.55 \mathrm{~kW})$

\begin{tabular}{|c|c|c|}
\hline power equipment & Rated power Watt & Qty \\
\hline Radio unit & 4300 & 1 \\
\hline Baseband & 2300 & 1 \\
\hline \multicolumn{3}{|c|}{ Power consumption equipment } \\
\hline \multicolumn{3}{|l|}{ Antenna equipment } \\
\hline RF feeder & 150 & 1 \\
\hline Remote mon \& safety & 100 & 1 \\
\hline \multicolumn{3}{|l|}{ Transmission equipment } \\
\hline $\begin{array}{l}\text { Signal transmitting } \\
\text { Auxiliary equipment }\end{array}$ & 200 & 1 \\
\hline Security and lighting & 300 & 1 \\
\hline Total & 8550 & \\
\hline
\end{tabular}

While the cooling unit is $5274 \mathrm{~kW}$, making the entire base station architecture power rating to be $13824 \mathrm{~kW}$

\section{RESULTS AND DISCUSSION}

Using the data in table 2 above to model the proposed base station site, the following are the results

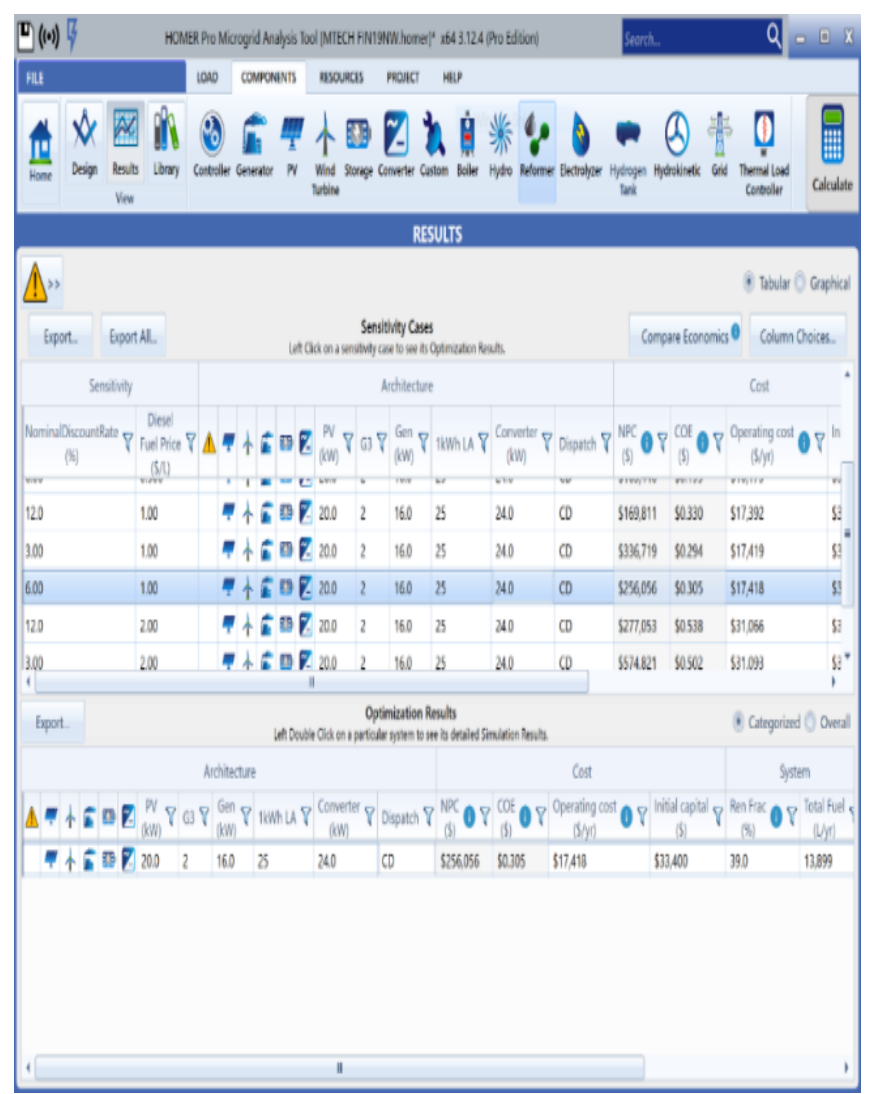

Fig. 11. Proposed System Simulation Sensitivity Result

\section{A : SENSITIVITY RESULT}

The result in figure 11 is the simulation result of the proposed system, which was simulated using a $6 \%$ nominal discount and $\$ 1 / \mathrm{L}$ of fuel, using $13.824 \mathrm{~kW}$ rated capacity. Table 3 and 4 are the representation of the electrical output of the simulation.

\begin{tabular}{lll}
\multicolumn{2}{l}{ TABLE III: GENERIC FLAT-PLATE PV ELECTRICAL SUMMARY } \\
\hline \hline Quantity & Value & Units \\
\hline Minimum Output & 0 & $\mathrm{~kW}$ \\
Maximum Output & 19.4 & $\mathrm{~kW}$ \\
PV Penetration & 54.8 & $\%$ \\
Hours of Operation & 6,840 & $\mathrm{hrs} / \mathrm{yr}$ \\
Levelized Cost & 0.0220 & $\$ / \mathrm{kWh}$ \\
\hline
\end{tabular}

\begin{tabular}{lll}
\multicolumn{2}{l}{ TABLE IV: GENERIC FLAT PLATE PV STATISTICS } \\
\hline \hline Quantity & Value & Units \\
\hline Rated Capacity & 20.0 & $\mathrm{~kW}$ \\
Mean Output & 12.11 & $\mathrm{~kW}$ \\
Mean Output & 345.8 & $\mathrm{kWh} / \mathrm{d}$ \\
Capacity Factor & 49.5 & $\%$ \\
Total Production & 124,488 & $\mathrm{kWh} / \mathrm{yr}$
\end{tabular}

From table 3 and 4 the results show the electrical production summary and general PV statistics, the major 
thing to note is the hours of operation per year, from the result PV operated throughout the year, though while operating there may be periods it might not produce a required amount of output to power the system, therefore the system is configured to use backup system which is Genset or Battery to power the system in the time of deficit in the system. While the existing system result as shown in figure 12 and table 4 shows the sensitivity of the simulation.

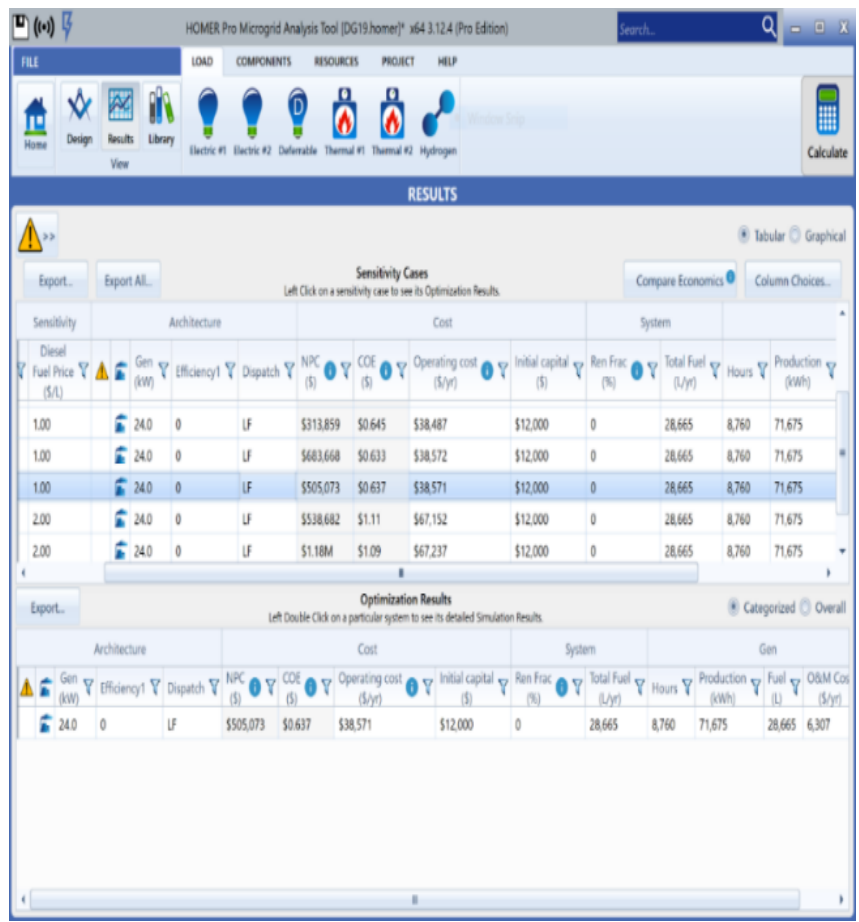

Fig 12. Existing System Simulated Sensitivity Result

\begin{tabular}{lll}
\multicolumn{2}{l}{ TABLE V: AUTO SIZE GENSET ELECTRICAL SUMMARY } \\
\hline \hline Quantity & Value & Units \\
\hline Electrical Production & $119,439,360$ & $\mathrm{kWh} / \mathrm{yr}$ \\
Mean Electrical Output & 13.18 & $\mathrm{~kW}$ \\
Minimum Electrical Output & 6.00 & $\mathrm{~kW}$ \\
Maximum Electrical Output & 21.0 & $\mathrm{~kW}$ \\
\hline \hline
\end{tabular}

\begin{tabular}{lll}
\hline \multicolumn{2}{l}{ TABLE VII : AUTO SIZE GENSET STATISTICS } & \\
\hline \hline Quantity & Value & Units \\
\hline Hours of Operation & 8,760 & $\mathrm{hrs} / \mathrm{yr}$ \\
Number of Starts & 3.00 & $\mathrm{starts} / \mathrm{yr}$ \\
Operational Life & 2.97 & $\mathrm{Yr}$ \\
Capacity Factor & 34.1 & $\%$ \\
Fixed Generation Cost & 2.52 & $\$ / \mathrm{hr}$ \\
Marginal Generation Cost & 0.236 & $\$ / \mathrm{kWh}$ \\
\hline \hline
\end{tabular}

The sensitivity results in both proposed and the existing system show that both systems have maximum output above the load power output of $13.824 \mathrm{~kW}$, meaning that the proposed system has the capacity to do some work as the existing system

Telecommunication base station in Nigeria is solely dependent on diesel genset, which runs 365 days non-stop except in the situation of servicing, system checks and upgrade..

However, table 8 shows the carbon emission comparison between existing system and the proposed system, the carbon dioxide and carbon monoxide in the existing system are 75,033 and 473 respectively while the proposed system has 264 and 1.79 respectively, the result shows that the new system has great improvement in all carbon emission even though is not completely removed from the system but the pollution is minimal.

TABLE VIII : CARBON EMISSION COMPARISON BETWEEN EXISTING AND NEW SYSTEM

\begin{tabular}{llll}
\hline \hline Pollutant & $\begin{array}{l}\text { DG Only } \\
\text { Quantity }\end{array}$ & $\begin{array}{l}\text { Hybrid } \\
\text { Quantity }\end{array}$ & Unit \\
\hline Carbon Dioxide & 75,033 & 264 & $\mathrm{~kg} / \mathrm{yr}$ \\
Carbon Monoxide & 473 & 1.79 & $\mathrm{~kg} / \mathrm{yr}$ \\
Unburned & & & $\mathrm{kg} / \mathrm{yr}$ \\
Hydrocarbons & 20.6 & 0.0728 & $\mathrm{~kg} / \mathrm{yr}$ \\
Particulate Matter & 2.87 & 0.109 & $\mathrm{~kg} / \mathrm{yr}$ \\
Sulphur Dioxide & 184 & 0.648 & $\mathrm{~kg} / \mathrm{yr}$ \\
Nitrogen Oxides & 444 & 2.04 & \\
\hline \hline
\end{tabular}

\section{CONCLUSION}

This project showcase how sustainable and environmentally friendly hybrid system is, which is based on PV\&WT with a DG set as a backup, which also includes some useful component such as Battery converter and Homer cycle controller, which is proposed for a reliable source of power supply for Base Transceiver Station. After evaluation and analysis, an environmentally friendly system is proposed, based on its economic viability and its major reduction in the cause of greenhouse gas emissions strength. The initial model which is DG only has a very high economic cost of $\$ 0.566 / \mathrm{kWh}$, whereas the proposed model has a muchimproved cost-friendly valued at $\$ 0.225 / \mathrm{kWh}$, it should also be noted that GHG emission of the existing DG system is very high at about $30,000 \mathrm{~kg} / \mathrm{yr}$ and above, while the new system 
is as low as $264 \mathrm{~kg} / \mathrm{yr}$. which is about $80 \%$ or more depending on the design chosen, which is a significant value over the previous model. Given all these facts I have proposed this new model a hybrid system based on Solar and wind power to supply the base station. However it should be noted that the proposed model provide cost-effective power supply to our Base Station and reduce the amount of OPEX in our Communication industry, due to drastic reduction in the amount of fuel used to run DG, and other factors like operation and maintenance cost of using DG only system, and also in terms of pollution it reduces environmental pollution greatly Simulation results shown that the PV/WT/diesel hybrid system has a total NPC cost of \$206, 238 and capital expenditure of $\$ 33,160$ with a total Carbon dioxide (CO2) of about $264 \mathrm{~kg} / \mathrm{yr}$ and this proposed system saves about $\$ 249,017$ of net present cost compared to diesel-only system and above 60,000 tons of carbon dioxide saves from the atmosphere. The study has illustrated that, although the cost of PV/WT/diesel hybrid system is very high during installation (initial cost), yet at the end has the least cost. From the environmental analysis of pollutant emission, one will prefer PV/WT/diesel hybrid system than using a dieselonly system. However, in conclusion, during my research I have verified the predictions by great researcher, scholars and so many literature reviews on this topic that when a $\mathrm{PV} / \mathrm{WT} /$ diesel hybrid system is used there a so many advantages which are superior to the diesel-only system used in powering BTS sites presently in Nigeria also both the economic and environmental perspective are promising if deployed.

\section{REFERENCES}

[1] A.A. Abdulkafi, T.S. Kiong, D. Chieng, A. Ting, J. Koh, Energy Efficiency Improvements in the Heterogeneous Network through Traffic Load Balancing and Sleep Mode Mechanisms. Wirel. Pers. Commun, 75, 2151-2164, 2014

[2] V.A Ani and A. N. Emetu, "Simulation and Optimization of Photovoltaic/Diesel Hybrid Power Generation Systems for Health Service Facilities in Rural Environments." Electronic Journal of Energy \& Environment 1.1, 2013

[3] A.M Aris, \& B.Shabani, "Sustainable Power Supply Solutions for Offgrid Base Stations. Energies", 8, 10904-10941, 2015

[4] G Auer, et al. "Energy efficiency analysis of the reference systems, areas of improvements and target breakdown,"EARTH Project Report, Deliverable D2.3, pp. 1-68, 2012

[5] B. I. Bakare and T. C Oguichen Appraisal of Green Communication Technology in GSM, International Journal of Electronics Communication and Computer Engineering Volume 9, Issue 3, ISSN (Online): 2249-071X, 2018

[6] B.I. Bakare et al. Appraisal of Global System for Mobile Communication (GSM) In Nigeria, American Journal of Engineering Research (AJER) e-ISSN: 2320-0847 P-ISSN: 2320-0936.Volume-6, Issue-6, pp-97-102, 2017

[7] M.O. Bello. "Effects of the Location of GSM Base Stations on Satisfaction of Occupiers and Rental Value of Proximate Residentia"' 2010

[8] S.H. Bukhari, B. "Asymmetrical fault correction for the Sensitive Loads Using a Currently Regulated Voltage Source Inverter. energies 9, 1962016.

[9] D. Calin, et al. "On femto deployment architectures and Macrocell Offloading Benefits in Joint Macro-femto Deployments," IEEE Communications Magazine, vol. 48, no. 1, pp. 26-32, 2010

[10] P.J Chung Green Radio the case for more efficient cellular base stations, (slides) UK-Taiwan ICT Workshop: Smart \& Green Communications, University of Taiwan, 2010.

[11] M. Deruyck, Power consumption model for macrocell and microcell base stations Trans. Emerg. Telecomm. Techno, 25, 320-333, 2014

[12] A.M. Eltamaly and A.A. Al-Shamma'a. "Optimal configuration for isolated hybrid renewable energy systems. J. Renew. Sustain. Energy, 8, 045502, 2016

[13] D. Feng."A Survey of Energy-Efficient Wireless Communications" IEEE Communication Survey. Tutor. 15,2013, 167-178, 2013
[14] J. Gambini, and U.Spagnoli, "Wireless Over Cable For Energy Efficient Femtocell Systems," In Proceedings Of The IEEE Globecom Workshops (GC'10), pp. 1464-1468, 2010.

[15] Gesi: Global e-Sustainability Initiative: Smart 2020. "Enabling the Low Carbon Economy in the Information Age". Retrieved from https://jwcn-eurasipjournals.springeropen.com/articles/10.1186/16871499-2012-142.2008

[16] Google search retrieved

from http://www.sacredsun.com/solution_112), 2017

[17] GSMA."Community Power: Using Mobile to Extend the Grid," London, UK, Retrieved From:http://www.Gsma.com/Mobile for development/wpcontent/uploads/2012/05/Community-Power-UsingMobile-to-Extend-the-Grid.pdf (accessed on 9 March 2018), 2010

[18] F. Han, et al. "Survey of strategies for switching off base stations in heterogeneous networks for greener 5G systems. IEEE, 4, 4959-4973, 2016

[19] Hou, Y. and D. I Laurenson. "Energy efficiency of high QoS heterogeneous wireless Communication network," in Proceedings of the IEEE 72nd 2010 Vehicular.

[20] J. Hoydis, and M. Debbah, "Green, cost-effective, flexible, small cell networks. IEEE Commun. Soc. MMTC 5, 23-26, 2010

[21] M Kundi. and H. P.Hutter. "Mobile phone base stations-Effects on wellbeing and health Pathophysiology 16 (2009) 123-135, 2009

[22] A. Mukherjee et al. "Femtocell based green power Consumption methods for the mobile network," Computer Networks, 57(1), pp.62178,2013

[23] T. C. Ou, C.M.Hong, "Dynamic operation and control of microgrid hybrid power Systems. Energy, 66, 314-323, 2014

[24] F. Richter, et al. "Traffic demand and energy Efficiency in heterogeneous cellular mobile radio networks," in Proceedings of the 71st IEEE Vehicular Technology Conference (VTC '10), pp.1-6, (2010

[25] Sulyman, A.I.; Nassar, A.; Samimi, M.K.; Maccartney, G.; Rappaport, T.S.; Alsanie, A. (2014) Radio propagation path loss models for 5G cellular networks in the $28 \mathrm{GHz}$ and $38 \mathrm{GHz}$ Millimetre-wave Bands. IEEE Commun. Mag, 52, 78-86.

[26] J. Wu, "Energy-Efficient Base Stations Sleep Mode Techniques in Green Cellular Networks: A Survey. IEEE Commun. Surv. Tutor, 17 803-826, 2015

[27] Zhang, M., Liu, X., Wang, W., Zhou, M. "Decomposition analysis of $\mathrm{CO}_{2}$ emissions from electricity generation in China. Energy Policy, 52, 159-165, 2013

[28] Y. Zhang, "Minimum cost solar power systems for LTE macro base stations. Comput. Netw, 112, 12-23, 2017

[29] X. Zhang. "Energy-efficiency study for two-tier Heterogeneous Networks (HetNet) Under Coverage Performance Constraints. Mobile Network. Appl, 18, 567-577, 2013

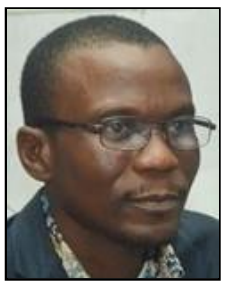

B. I. Bakare holds a Bachelor of Engineering (B.Eng.) Degree in Electrical Engineering; 21 from Ondo State University, Ado Ekiti, ( Now University of Ado Ekiti, Ekiti State), Master of Engineering (M.Eng.) Degree in Electrical/Electronic Engineering from University of Port Harcourt, Nigeria and he is currently a $\mathrm{PhD}$ (Communication Engineering) Researcher of Nnamdi Azikiwe University (Unizik), Awka, Anambra State. He holds a Category One Electrical Wiring License. He is a COREN registered Engineer, a Corporate Member of Nigeria Society of Engineers (NSE), a member of International Association of Engineers (I A ENG) and an active member of Nigeria Institute of Electrical and Electronics Engineers (NIEEE). He is presently a lecturer in the Department of Electrical Engineering, Rivers State University, Port Harcourt., Nigeria. He is married with children.

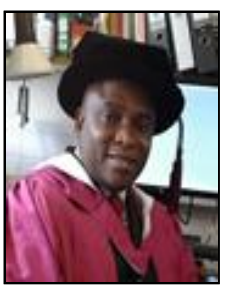

Sunny Orike received his B. Tech. in Computer Engineering from Rivers State University of Science and Technology (now Rivers State University); M.Sc. in Computing and M.Phil. in Computational Intelligence, both from Robert Gordon University, Aberdeen, United Kingdom; and Ph.D in Artificial Intelligence from Heriot-Watt University, Edinburgh, United Kingdom.

Dr. Orike is an active member of several professional bodies, including Council for the Regulation of Engineering in Nigeria, Nigeria Institution of Electrical Electronic Engineers and International Association of Engineers. He is a Senior Lecturer and former Head, Department of Electrical \& Computer Engineering, Rivers State University, Port Harcourt, Nigeria.

Dr. Orike has published in several reputable journals, presented at both local and international conferences, and acts as a reviewer to several journals. 
He is a Facilitator with the National Open University of Nigeria, and External Assessor for Port Harcourt Polytechnic, Nigeria. He is married with children, and can be reached on: orike.sunny@ust.edu.ng.
D.I. Oko was born in Cross River State Nigeria, in 1985, and holds a B. Engr. degree in Electrical Electronic Engineering, in Cross River State University of Science and Technology, in 2010. He is presently a master student at Rivers State University, a Graduate Member of Nigeria Society of Engineers (NSE) his research interests are on, The trend of electromagnetic radiation of a base station and Evaluation and analysis of the deployment of green communication Technology in GSM 